\title{
Development Study Of T-Z Curve Generated From Kentledge System And
}

\section{Bidirectional Test}

\author{
N. U. Rachmayanti ${ }^{1 *}$, P. P. Rahardjo ${ }^{2}$. \\ $I^{*}$ Department of Civil Engineering, Faculty of Engineering, Parahyangan Catholic University. \\ ${ }^{2}$ Lecture in Department of Civil Engineering, Faculty of Engineering, \\ Parahyangan Catholic University. \\ Email : ${ }^{*}$ nisa.ur@gmail.com.
}

\section{A R T I C L E I N F O \\ Article History : \\ Article entry : 16-09-2020 \\ Article revised : 24-09-2020 \\ Article received : 27-10-2020 \\ Keywords : \\ Bidirectional, Kentledge, Pile Load Test, VWSG.}

IEEE Style in citing this article : [1] $M$. Amirmojahedi, $M$. Saberizade, M. Sadeght, $M$. Keshtkar, "Fiber Optic Sensors in Geotechnical Engineering”, 5th International Conference on Geotechnical Engineering and Soil Mechanics, 2016.

\section{A B S T R A C T}

Pile loading tests to check the bearing capacity to support large loads. We can also use it to measure its deflection under lateral load. There are two tests: the axial static pile load test (Kentledge) and the two-directional static pile load test (Bidirectional). T-Z curve as the result analysis based on the instrumented pile test data describes the load distribution and mobilized skin friction along with the pile. Numbers of Vibrating Wire Strain Gauge (VWSG) mounted in several depths of the bored pile and two tell-tale on top and toe of the pile used as primary data in this research. This research to determine the different distribution of mobilized skin friction. The pile from two different pile load test methods from the calculated $t-z$ curve as the study developed from both methods of pile test. The research results that the kentledge system has bigger mobilized skin friction than in bidirectional test.

\section{Introduction}

Invalidating the High-Rise Building Project's design in Jakarta, two different static instrumented loading test methods performed. As shown in the following figure, the area of study is surrounded by other high-rise buildings and located at the road's side. This project will accommodate all data to fulfill the analysis of this research.

The two different pile load tests performed in this project are Head-Down Static Load Test and Bidirectional Test. Head-Down Load Test, known as Kentledge, accommodates loads from the top of the pile directly towards the pile toe. Meanwhile, Bidirectional accommodates 
loads in two directions, upward and downward, through the hydraulic jack placed in a certain depth of pile called Osterberg cell. Therefore, these upward loads will give tension force through a pile in an upward direction.

These pile load tests are instrumented with vibrating wire strain gauges at a certain depth along with the pile. According to Fellenius (2018), data from strain gauges provides records of load movement or shear stress and represents the data of a pile element which can be described in the t-z function [1] [2]. The t-z curve may be derived from the pile movement's soil behavior under the axial load during the pile load test.

This research investigates piles' behavior under load using Kentledge and Bidirectional test results based on the load distribution. The t-z curve portrays the load distribution and determines the maximum mobilized skin friction after the load test is conducted [3].

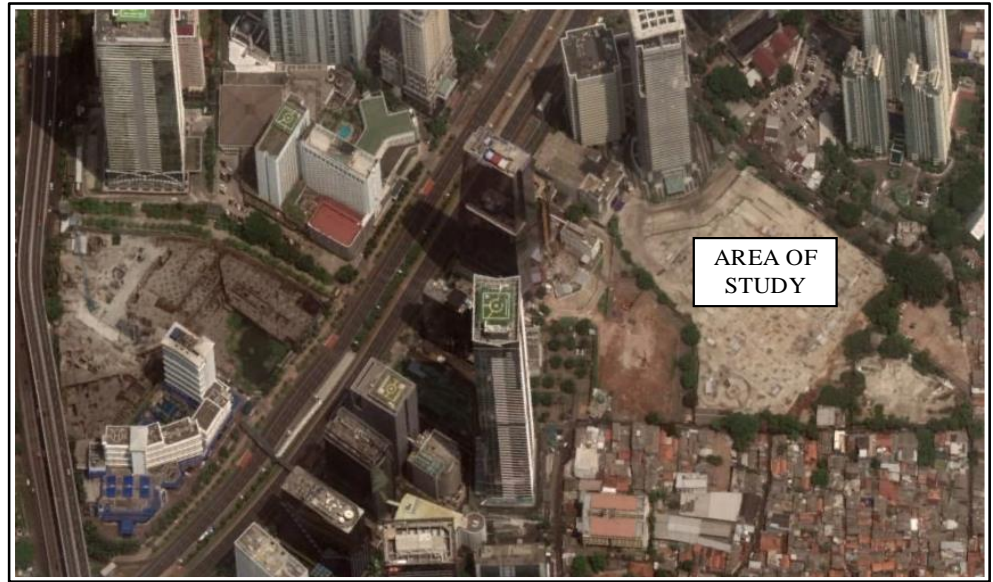

Source: Google Earth. (2020).

Figure 1. Area of Study.

\section{Literature Review}

The t-z curve suggested by Seed ad Reese (1957) is an analysis method to determine the axial movement of the pile under axial load. The $\mathrm{t}-\mathrm{z}$ curve procedures generate the relationship of mobilized skin friction and the movement of the pile along with the bored pile during stages of loading. Empirically, the t-z curve is obtained based on the load distribution from load transfer curve analysis. The t-z curve behavior is much affected by most pile parameters such as diameter, stiffness, length, and strength [4].

Finite difference equations are employed to achieve compatibility between pile displacement and the load transfer along with the pile and between displacement and resistance at the tip of the pile. This method uses Seed and Reese (1957). The t-z difference method assumes the Wrinkler concept, that is, the load transfer at a certain pile section and the pile tip 
resistance are independent of the pile displacement elsewhere [5].

Load distribution develop from strain data obtained by strain gauge record during pile load test [6][7]. Head-Down Load Test generates load in one direction from the top of the pile until it reaches the pile toe, which results in compression that causes a bigger stress zone around the pile [8]. In contrast to a conventional head-down test, a bidirectional test establishes load in two directions, upward and downward. The load, provided by the hydraulic jack called Osterberg cell at a certain pile depth causes the pile to produce two different stress zones in the upper and lower segments of the pile, as shown in Figure 2. The lower segment of the pile develops compression force and tension in the upper segment [9].

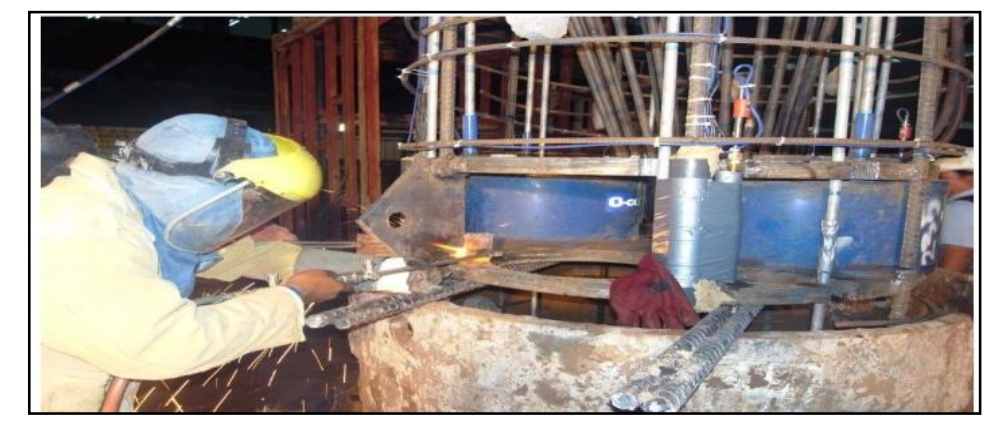

Source : Instrumentation Final Report of BP 38. (2013).

Figure 2. Hydraulic Jack Osterberg Cell.

As there is tension force going upwards the upper segment of the pile, this may cause a smaller amount of mobilized skin friction along the upper segment caused by the smaller stress zone affected by the upward loads[10]. Unlike the head-down test, to develop the t-z curve from bidirectional test data, the upward-downward movement in one equivalent top load curve generates the load and movement in one direction to be calculated into load transfer analysis[11].

\section{Research Method}

This research is conducted through several steps such as soil investigation to examine the soil condition, primary data collection from pile load tests performed, data analysis, and conclusion.

The tests conducted were pile loading test with kentledge system and bidirectional test. In this project, both Kentledge and bidirectional tests conducting in two different locations with similar soil conditions. These two methods on two $1.5 \mathrm{~m}$ diameter bored piles. Kentledge 
system was conducted in a bored pile in BP 24 (depth of $64.5 \mathrm{~m}$ ), while the bidirectional test in a bored pile in BP 38 (depth of $59.20 \mathrm{~m}$ ).

During pile load test using the kentledge system, the pile is compressed gradually by the axial load with enough time within the load. Pile settlement record using a dial gauge. The load used for each step depends on the building around the area. In this project, the pile is compressed under $200 \%$ axial load [12]. Then it is gradually decreasing which is usually known as unloading. The illustration of the static load test is show in the following figure.

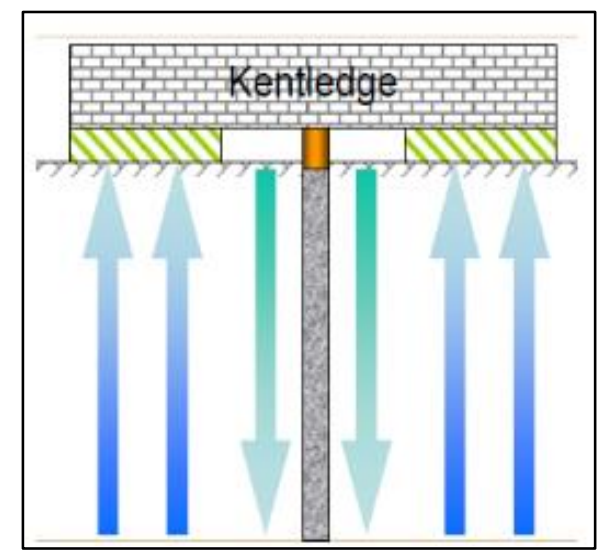

Source : England, 2010.

Figure 3. Illustration of Static Loading Test (Kentledge).

The bidirectional test consists of a jacking system on both piles with a head-down position where the pile pushes down against counterweight or reaction [13]. The jacking cylinder is between the two bearing plates forming a two-way cell, and locations in a very strategic place between the friction pile can compare the resistance of the pile above and below the pile. The following figure shows the illustration of the bidirectional test.

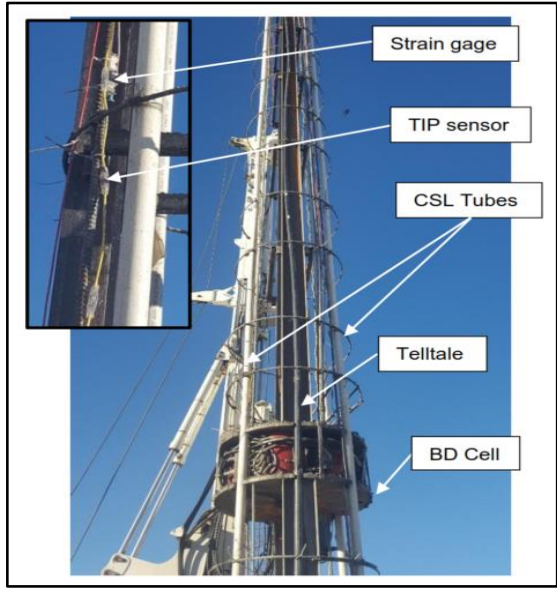

Source : Fellenius \& Salem, 2017.

Figure 4. Illustration of Bidirectional Test. 


\section{Results and Discussions}

\subsection{Instrumentation Result.}

For checking information, pile tests were conducted on-site. Both methods w to verify the differences between the two methods. According to the test conducted on-site, the bidirectional test has a more efficient time than the kentledge system. As shown in the following figure, the kentledge system shown as BP 24 needs more time to do the work, almost 70-hour work. Meanwhile, bidirectional shown as BP 38 can give less time to work about 57 hours.

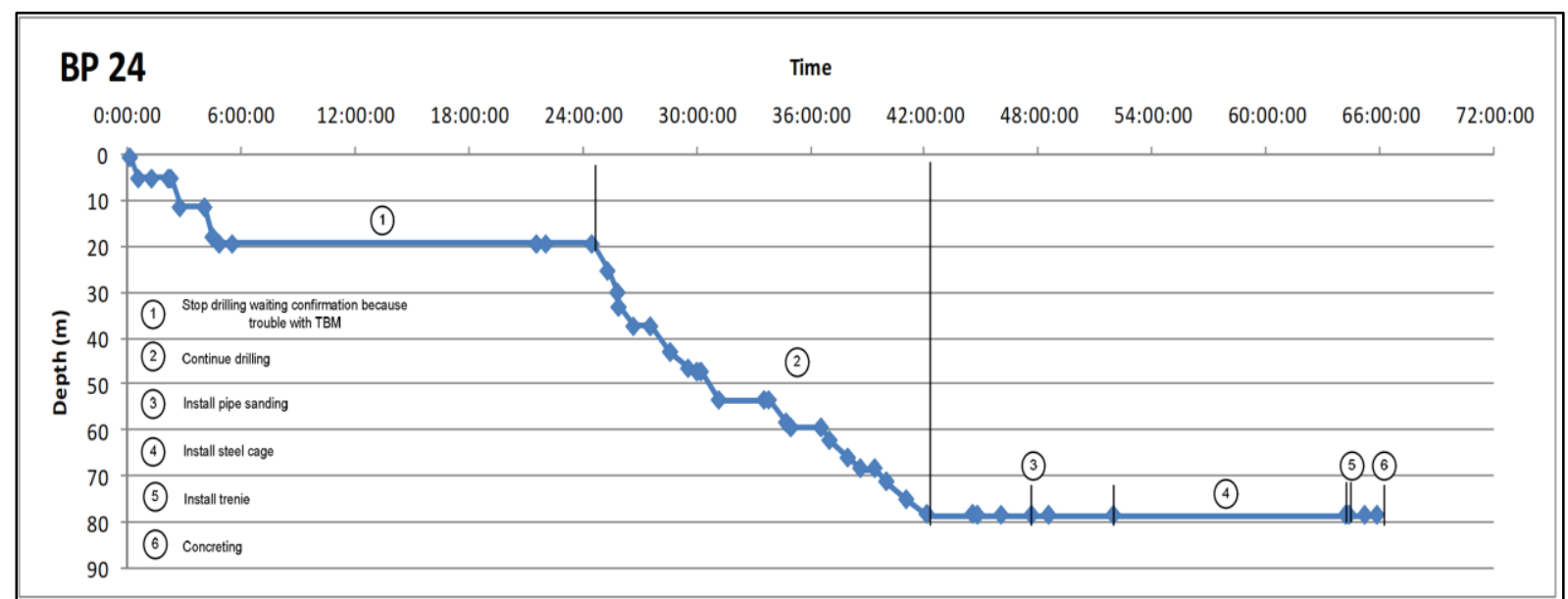

(a)

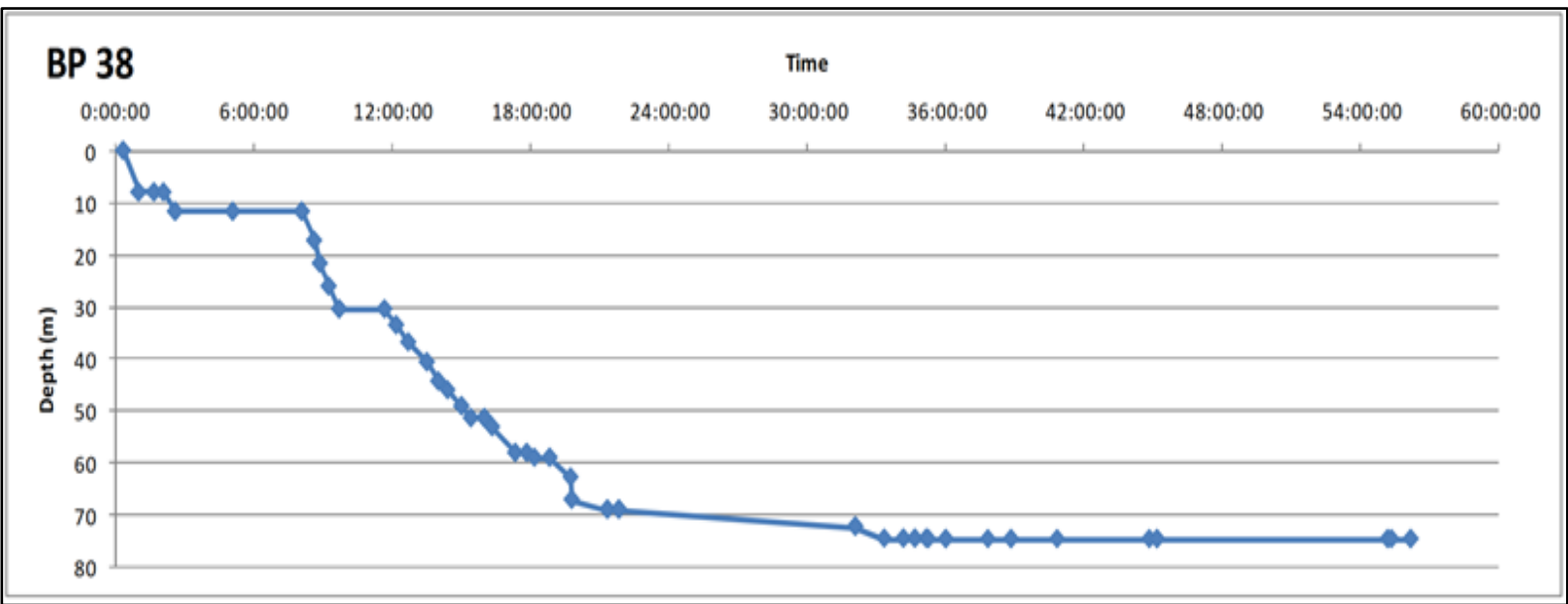

(b)

Source: Instrumentation Final Report of BP 24 and BP 38. (2013).

Figure 5. Time Efficiency of Kentledge System and Bidirectional Test, (a) Duration of Kentledge System; (b) Duration of Bidirectional Test.

According to the field's execution, significant differences shown that it is true headdown pile loading test gives a bigger result in mobilized skin friction along with the pile than the bidirectional test shown in the following figure. 


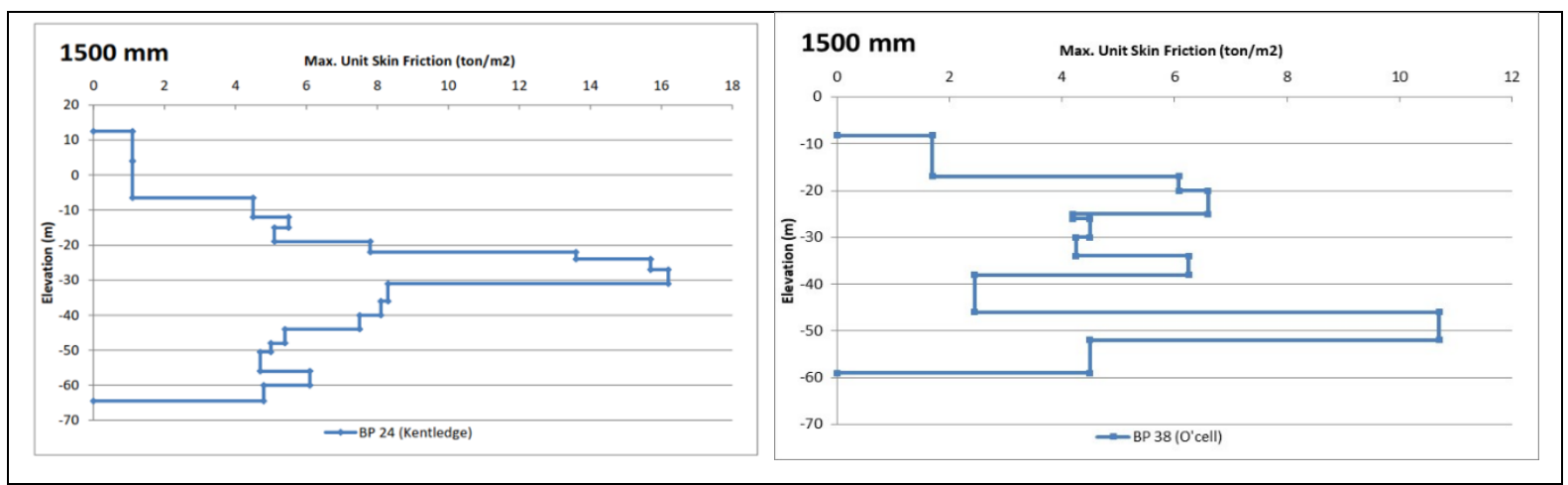

Source: Instrumentation Final Report of BP 24 and BP 38. (2013).

Figure 6. Interpretation Results of Kentledge System and Bidirectional Test.

Figure 6 shows that the bidirectional test shown as BP 38 gives smaller maximum skin friction than the kentledge system by $6 \mathrm{t} / \mathrm{m} 2$ difference. The tz curve calculation will show that the bidirectional test has smaller maximum skin friction than the kentledge system.

1. Head-Down Static Loading Test (Kentledge).

Soil stratification is classified based on boring in two locations of pile loading test. On the head-down loading test (BP 24), there is bore log BH-04 that can use to assess the pile test result. Based on the borehole, soil condition in area BP 24 is dominant by clayey soil with several sand lenses. On the surface, there is a soft clay layer. Medium clay layer is identified in $1 \mathrm{~m}$ to $18 \mathrm{~m}$ depth, followed by stiff to very stiff sandy silt layer in $34 \mathrm{~m}$ depth. A medium dense sand layer is identified in the depth of $35 \mathrm{~m}$. The consistency is increasing throughout the boring.

Table 1. Soil Stratification And Pile Segment.

\begin{tabular}{cccccc}
\hline Segment & \multicolumn{2}{c}{ Elevation $(\mathrm{m})$} & & Pile Length $(\mathrm{m})$ & Soil Type \\
\hline A & 12.5 & - & 4 & 8.5 & Medium Clay \\
B & 4 & - & -6.5 & 10.5 & Stiff to V.Stiff Clay \\
C & -6.5 & - & -12 & 5.5 & Sandy Silt, Stiff to V. Stiff \\
D & -12 & - & -15 & 3 & Sandy Silt, Stiff to V. Stiff \\
E & -15 & - & -19 & 4 & Very Dense Sand \\
F & -19 & - & -22 & 3 & Sandy Silt, Stiff to V. Stiff \\
G & -22 & - & -24 & 2 & Sandy Silt, Stiff to V. Stiff \\
H & -24 & - & -27 & 3 & Very Dense Sand \\
I & -27 & - & -31 & 4 & Hard Clay \\
J & -31 & - & -36 & 5 & Very Dense Sand \\
K & -36 & - & -40 & 4 & Sandy Silt, Hard \\
L & -40 & - & -44 & 4 & Sandy Silt, Hard \\
M & -44 & - & -48 & 4 & Hard Clay \\
N & -48 & - & -50.5 & 2.5 & Hard Clay \\
O & -50.5 & - & -56 & 5.5 & Hard Clay \\
P & -56 & - & -60 & 4 & Hard Clay \\
Q & -60 & - & -64.5 & 4.5 & Hard Clay \\
R & -64.5 & & & & Hard Clay \\
\hline Source & &
\end{tabular}

Source : Instrumentation Final Report of BP 24. (2013). 
Table 1 shows the soil stratification and pile segment on each depth of instrumentation of vibrating wire strain gauge installed. There are 18 strain gauges installed at depth. Each telltale extensometer installs at a depth of its COL (EL.-8.2m and $-65.0 \mathrm{~m})$.

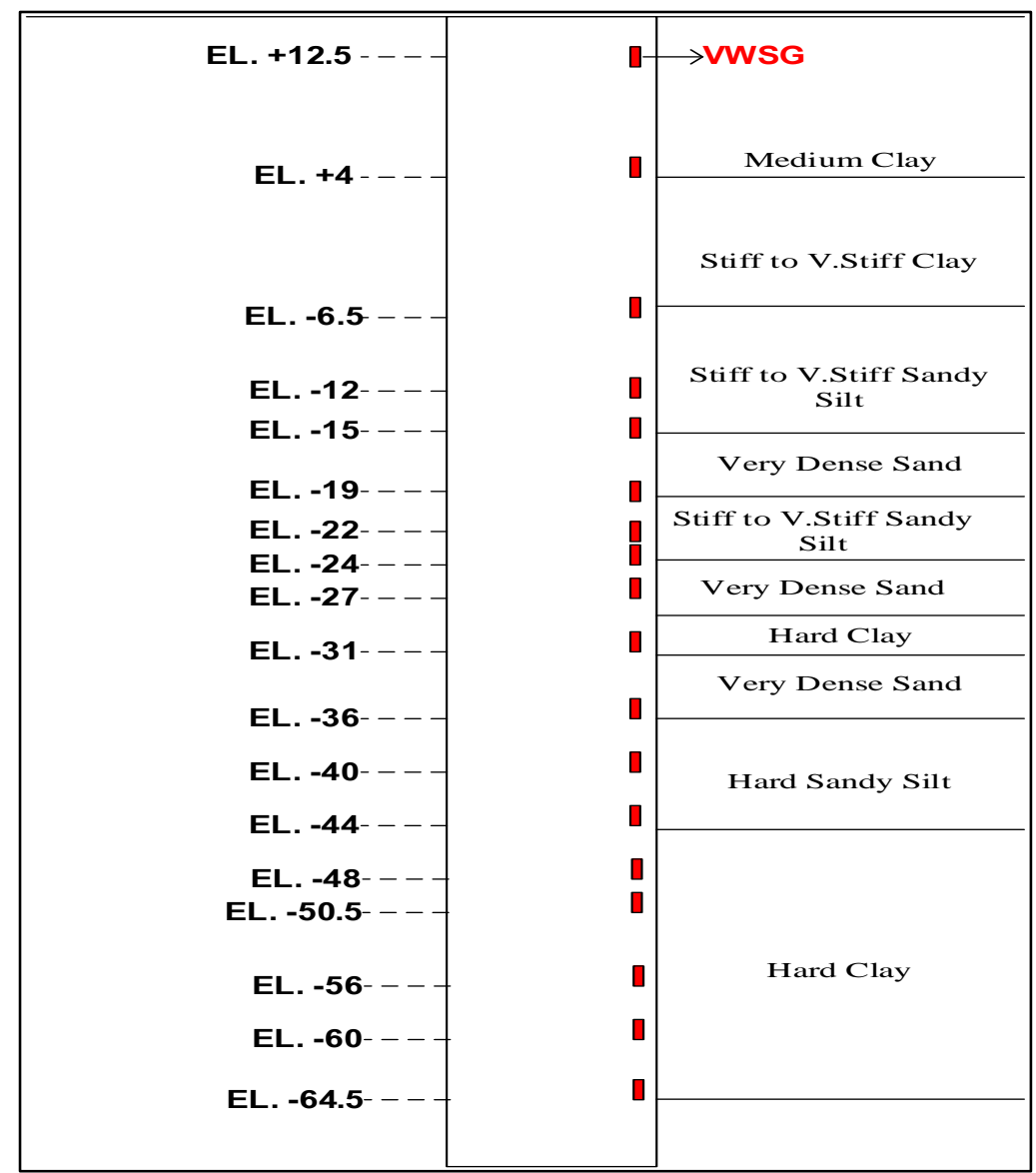

Source : Instrumentation Final Report of BP 24. (2013).

Figure 7. Illustration of VWSG installation on Bored Pile.

Figure 7. shows the illustration of every strain gauge is installed. The tell-tale extensometer consists of a steel rod with $9.5 \mathrm{~mm}$ diameter, hooked in the anchor inside the pile, and placed inside a PVC pipe with $25 \mathrm{~mm}$ diameter. Four dial gauges with the accuracy of $\pm 0.01 \mathrm{~mm}$ used to measure the settlement from the steel road, aligned with the reference beam.

A head-down static loading test is conducted based on ASTM D1143-07 [6]. The procedure uses a reaction system, where the load on top of the pile is affected by friction capacity from four reaction piles connected to the beam frame. Axial load established by the hydraulic jack Osterberg cell is 1000 tons with a designated load of 1150 tons, and loading is conducted in four cycles. Maximum load on each cycle contains 575 ton (50\%), 1150 ton (100\%), 1725 ton (150\%), 2013 ton (175\%) and 2300 ton (200\%). This research presents the fourth cycle to be analyzed. 
According to the loading test, the pile settlement for each designed load show in Table

2.

Table 2. Pile Settlement And Stage Loading At Fourth Cycle.

\begin{tabular}{cc}
\hline $\begin{array}{c}\text { Load } \\
\text { (ton) }\end{array}$ & $\begin{array}{c}\text { Settlement } \\
(\mathrm{mm})\end{array}$ \\
\hline 0 & 4.72 \\
575 & 7.57 \\
1150 & 11.13 \\
1725 & 15.48 \\
2013 & 19.81 \\
2300 & 28.52 \\
\hline
\end{tabular}

Source: Instrumentation Final Report of BP 24. (2013).

Table 3 shows the average strain measured by vibrating wire strain gauge (VWSG) on each stage of loading in the fourth cycle at each depth along with the pile.

Table 3. VWSG Result.

\begin{tabular}{|c|c|c|c|c|c|c|c|c|c|c|c|}
\hline \multirow{2}{*}{ SEGMENT } & \multirow{2}{*}{$\begin{array}{c}\text { VWSG } \\
\text { Depth (m) }\end{array}$} & \multicolumn{10}{|c|}{$\Delta$ at APPLIED LOAD } \\
\hline & & 0 & 575 & 1150 & 1725 & 2012.5 & 2300 & 1725 & 1150 & 575 & 0 \\
\hline A & 12.5 & 0 & 160.5 & 283.75 & 417.25 & 494 & 630.5 & 518.25 & 366 & 227 & 38.75 \\
\hline B & 4 & 0 & 148.75 & 272.75 & 407 & 483 & 618 & 342.75 & 242.5 & 148.75 & 14 \\
\hline $\mathrm{C}$ & -6.5 & 0 & 135.5 & 261 & 394.5 & 470.5 & 603.5 & 391.75 & 261.25 & 156.5 & 13.25 \\
\hline $\mathrm{D}$ & -12 & 0 & 111.25 & 233 & 366.5 & 441.75 & 571.25 & 371.25 & 249.5 & 159 & 25 \\
\hline $\mathrm{E}$ & -15 & 0 & 97.75 & 216 & 348 & 423 & 549.75 & 275.5 & 215.25 & 133.25 & 17.75 \\
\hline $\mathrm{F}$ & -19 & 0 & 80.75 & 194 & 325 & 399.25 & 523.25 & 332.75 & 275.75 & 181 & 45.5 \\
\hline G & -22 & 0 & 62 & 170.75 & 298.75 & 372.25 & 493 & 379.5 & 335.5 & 246.25 & 63.25 \\
\hline $\mathrm{H}$ & -24 & 0 & 49 & 154.25 & 272 & 341.5 & 457.75 & 299.5 & 265.25 & 194.5 & 64.5 \\
\hline I & -27 & 0 & 24 & 110 & 225.25 & 288.25 & 397 & 266.25 & 230.25 & 173.5 & 59.75 \\
\hline $\mathbf{J}$ & -31 & 0 & 8.75 & 74 & 165.25 & 222.75 & 313 & 235.5 & 228.5 & 205.5 & 48.5 \\
\hline $\mathrm{K}$ & -36 & 0 & 1 & 32.5 & 124 & 177.25 & 259.5 & 282.75 & 278 & 263 & 49.5 \\
\hline $\mathrm{L}$ & -40 & 0 & 0.5 & 17.5 & 101 & 149.5 & 217.5 & 235 & 232 & 223.5 & 70.75 \\
\hline $\mathbf{M}$ & -44 & 0 & 0.25 & 14.5 & 82 & 121 & 178.75 & 149.25 & 127 & 126 & 82.5 \\
\hline $\mathrm{N}$ & -48 & 0 & 0.25 & 11.5 & 61 & 97.5 & 164 & 147 & 145.75 & 142.25 & 122.25 \\
\hline $\mathrm{O}$ & -50.5 & 0 & 0.25 & 9.75 & 51 & 83.75 & 134.5 & 116.5 & 115.5 & 112.5 & 99 \\
\hline $\mathrm{P}$ & -56 & 0 & 0.5 & 8 & 29 & 56.5 & 101.5 & 71.5 & 71.25 & 70 & 62.25 \\
\hline Q & -60 & 0 & 0.25 & 6.75 & 20.25 & 43.5 & 86.25 & 38.75 & 38.75 & 37.75 & 33.75 \\
\hline $\mathrm{R}$ & -64.5 & 0 & 0.5 & 3.5 & 16.25 & 31 & 70.75 & 18.75 & 18.75 & 18.5 & 16.5 \\
\hline
\end{tabular}

Source: Instrumentation Final Report of BP 24. (2013).

\section{Bidirectional Test.}

On a bidirectional test (BP 38), BH-03 is used as the reference bore log for soil classification conducted side by side with BP 38. According to the borehole, there is a fill material $2.5 \mathrm{~m}$ thick. There is medium clay until $18 \mathrm{~m}$ depth. The soft soil layer is $5 \mathrm{~m}$ thick then followed by hard clay until the end of boring. A dense sand layer identification at few certain depths. 
Table 4. Soil Stratification And Pile Segment.

\begin{tabular}{|c|c|c|c|c|c|}
\hline Segment & Elev & & & $\begin{array}{l}\text { Pile } \\
\text { Length } \\
\text { (m) }\end{array}$ & Soil Type \\
\hline $\mathrm{A}$ & -8.3 & - & -16.9 & 8.5 & Sandy Silt, Stiff to V.Stiff \\
\hline $\mathrm{B}$ & -16.9 & - & -19.9 & 10.5 & Sandy Silt, Stiff to V.Stiff \\
\hline $\mathrm{C}$ & -19.9 & - & -24.9 & 5.5 & Dense Sand \\
\hline $\mathrm{D}$ & -24.9 & - & -25.9 & 3 & Sandy Silt, Stiff to V.Stiff \\
\hline $\mathrm{E}$ & -25.9 & - & -29.9 & 4 & Sandy Silt, Stiff to V.Stiff \\
\hline $\mathrm{F}$ & -29.9 & - & -33.9 & 3 & Stiff to V.Stiff Clay \\
\hline $\mathrm{G}$ & -33.9 & - & -45.2 & 2 & Hard Clay \\
\hline $\mathrm{H}$ & -45.2 & - & -52.2 & 3 & Hard Clay \\
\hline I & -52.2 & - & -59.2 & 4 & Hard Clay \\
\hline $\mathrm{J}$ & -59.2 & - & & 5 & Hard Clay \\
\hline
\end{tabular}

Source: Instrumentation Final Report of BP 38. (2013).

Table 4 shows the soil stratification and pile segment at each depth the instrumentation is installed along with the pile. There are 10 strain gauges installed at few depths. Both tell-tale extensometers are installed at a depth of their COL (EL. $-8.3 \mathrm{~m}$ to $59.2 \mathrm{~m}$ ).

Pile with $1.5 \mathrm{~m}$ diameter drilled into the depth of $-60.30 \mathrm{~m}$, under a layer of slurry bentonite. The bidirectional test's loading procedure has two hydraulic jacks of Osterberg cells with a diameter of $610 \mathrm{~mm}$, at a depth of $22 \mathrm{~m}$ above the pile toe. The load on the o-cell calibrated into 1.36 tons.

Based on the literature, the bidirectional test establishes two-directional loadings. Hence pile movement measured in this pile test is generated into two directions, upward and downward movement [14]. The load was corrected with the designed load given on the top pile.

Table 5. Pile Movement During Load Test.

\begin{tabular}{cccccc}
\hline \multirow{2}{*}{ Load (ton) } & \multicolumn{2}{c}{ Max. Settlement } & & Top Pile Load (ton) & Corrected Load (ton) \\
\cline { 2 - 3 } \cline { 5 - 5 } & Cell Top & Cell Bot & & & \\
\cline { 2 - 3 } 0 & 0 & 0 & & 113 & 0 \\
264 & 0.06 & -1.79 & & 113 & 151 \\
486 & 0.84 & -4.23 & 113 & 373 \\
699 & 4.9 & -25.89 & 113 & 586 \\
792 & 9.34 & -45.02 & 113 & 679 \\
896 & 19.56 & -115.9 & 113 & 783 \\
\hline
\end{tabular}

Source : Instrumentation Final Report of BP 38. (2013). 
The bidirectional test shows two-way settlement during the load test. As shown in Table 5, on each step of loading, maximum settlement occurs during the load test on cell top and bottom. On this test, the top pile load (buoyancy weight) placed axially is 113 tons. On a bidirectional test, the load has to be corrected with the buoyancy weight itself, and it is called a corrected load. This corrected load is the data that will be used for analysis afterward. The following figure shows the soil condition of the location where a bidirectional test was undertaken.

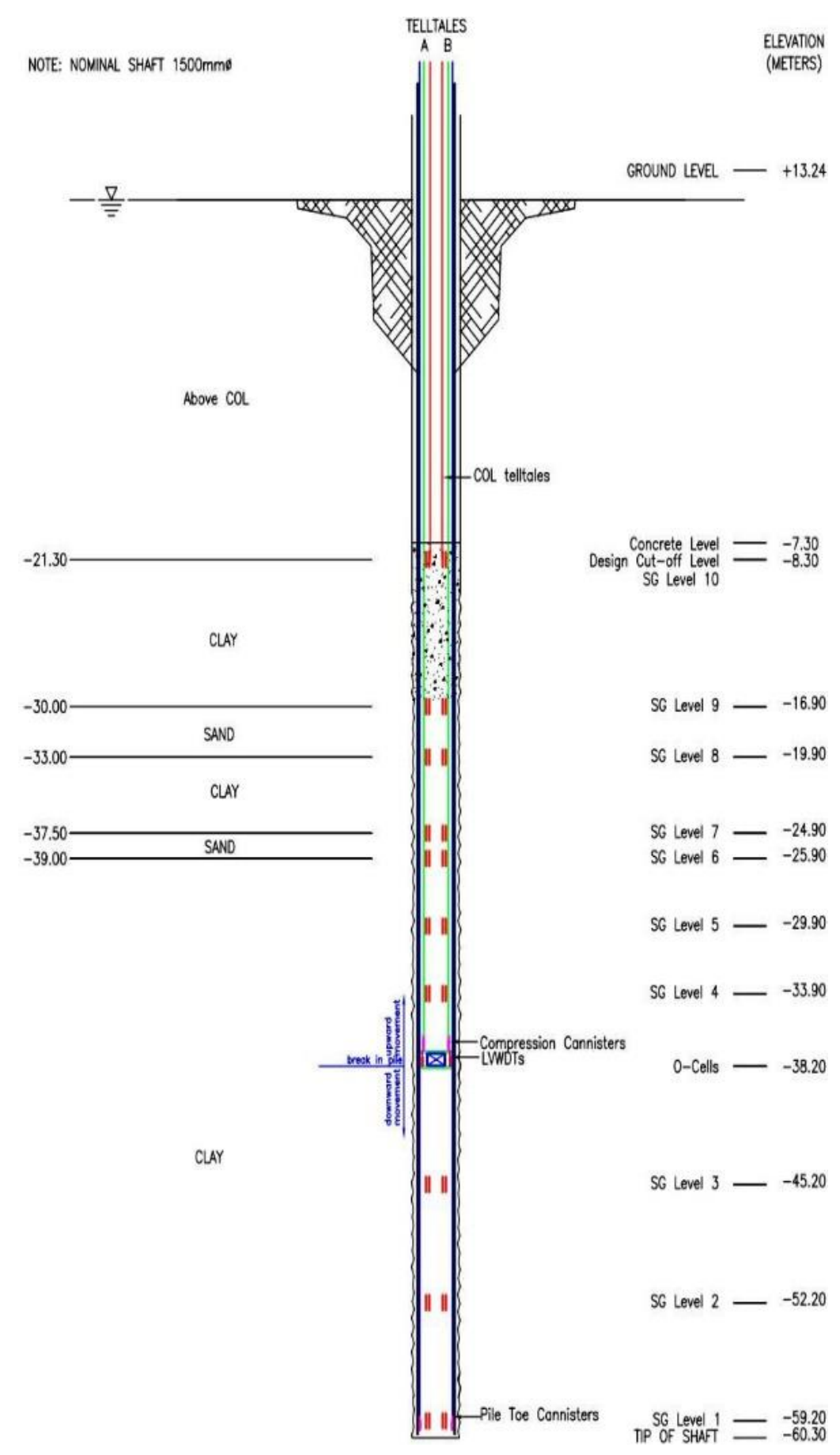

Source : Instrumentation report of BP 38. (2013).

Figure 8. Illustration of VWSG installation. 


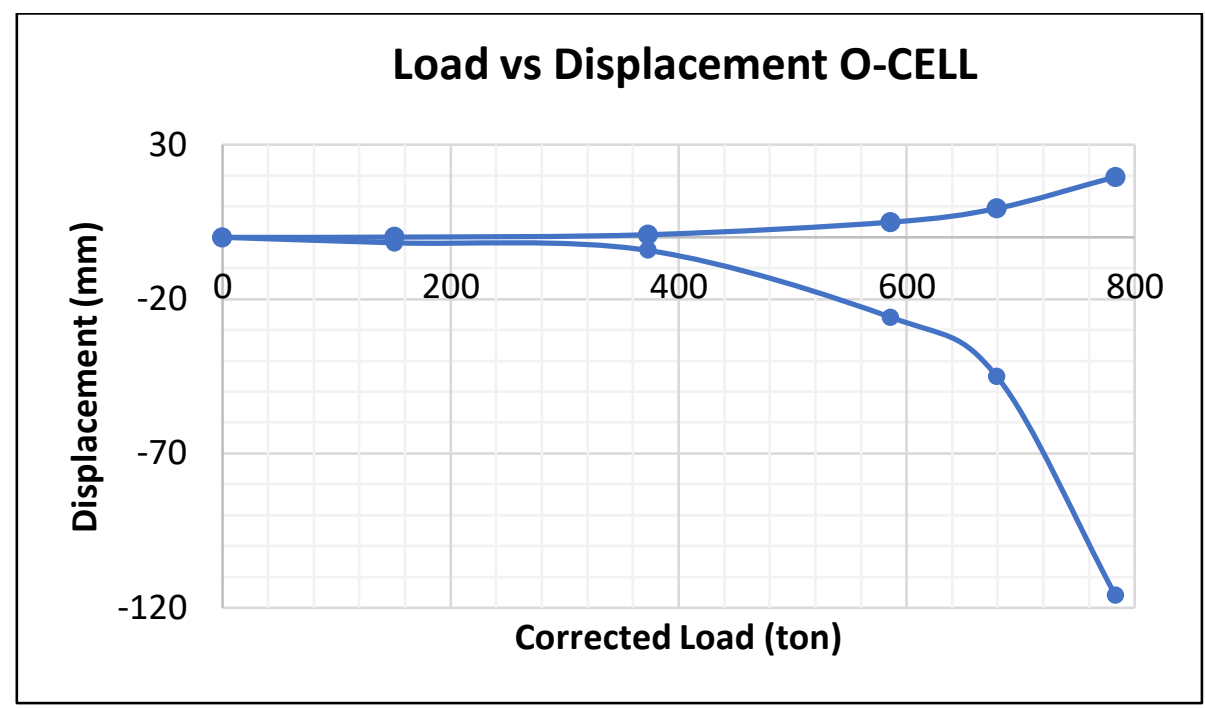

(a)

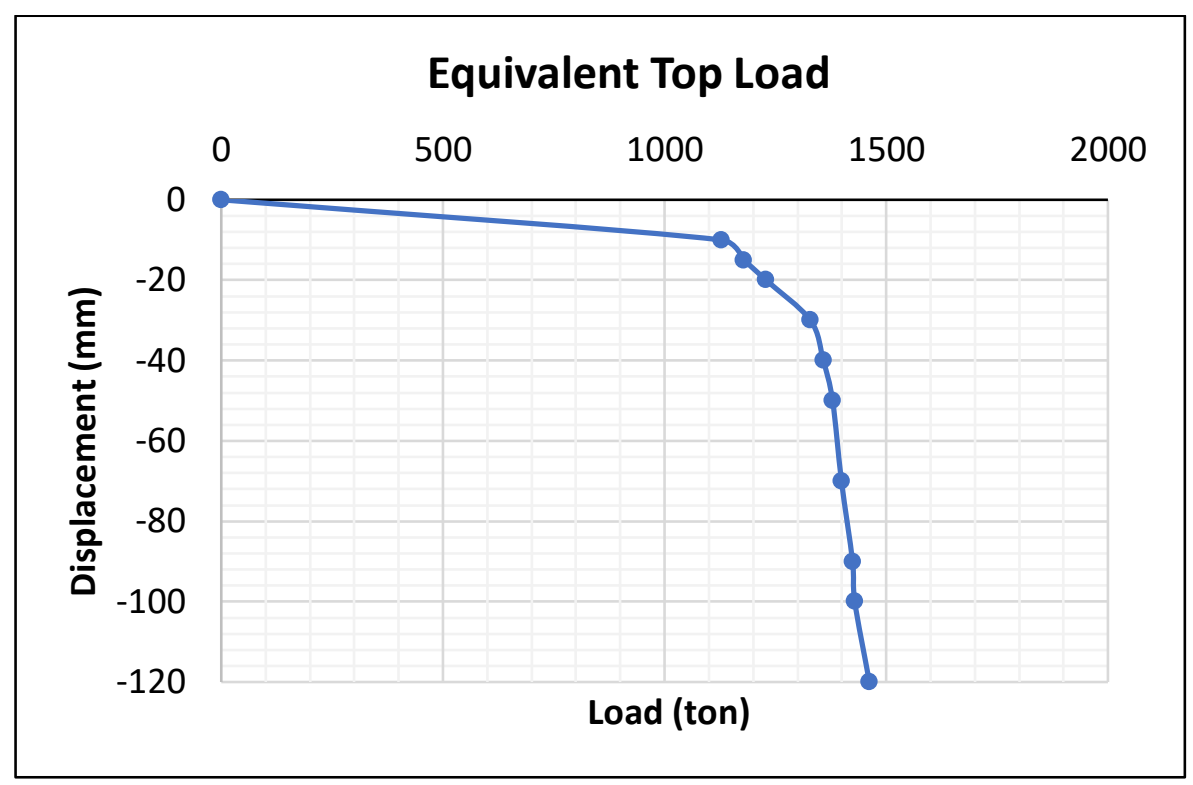

(b)

Source : Instrumentation Final Report of BP 38. (2013).

Figure 9. (a) Load vs displacement; (b) Equivalent top load

According to the bidirectional test's load vs. settlement curve, the equivalent top load curve can be determined to measure the settlement from the top of the pile. Based on Kim and Chung (2012), piles for axial load are designed to function similarly to a head-down test, and the design load is determined after combining shaft and toe resistance. Thus, a method to construct an equivalent head-down load-movement curve is needed [15]. 


\subsection{The T-Z Curve.}

To determine the friction of mobilized skin along the pile, it is necessary to do load transfer analysis and the depth of the pile [16]. Load transfer analysis develops into a curve that shows the relationship of skin friction and the pile movement at each segment, whereas instrumentation of strain gauge is installed [17].

1. Head-Down Static Loading Test (Kentledge).

A strain gauge instrumented on the pile during the pile loading test can produce a load distribution curve through the strain measured in the gauge installed [7]. Hence, the fourth cycle's load distribution curve in each load stage show in Figure 10.

Figure 10 shows the load distribution in each stage loading. The curve shows that during loading at $200 \%$ load, the load has been distributed throughout the pile's depths until the pile toe. I can see this on the depth of $-64.5 \mathrm{~m}$ that the load distribution is 258 tons. The load distribution curve is then developed into the t-z curve that shows the mobilized skin friction along the pile during the loading test [18] [19].

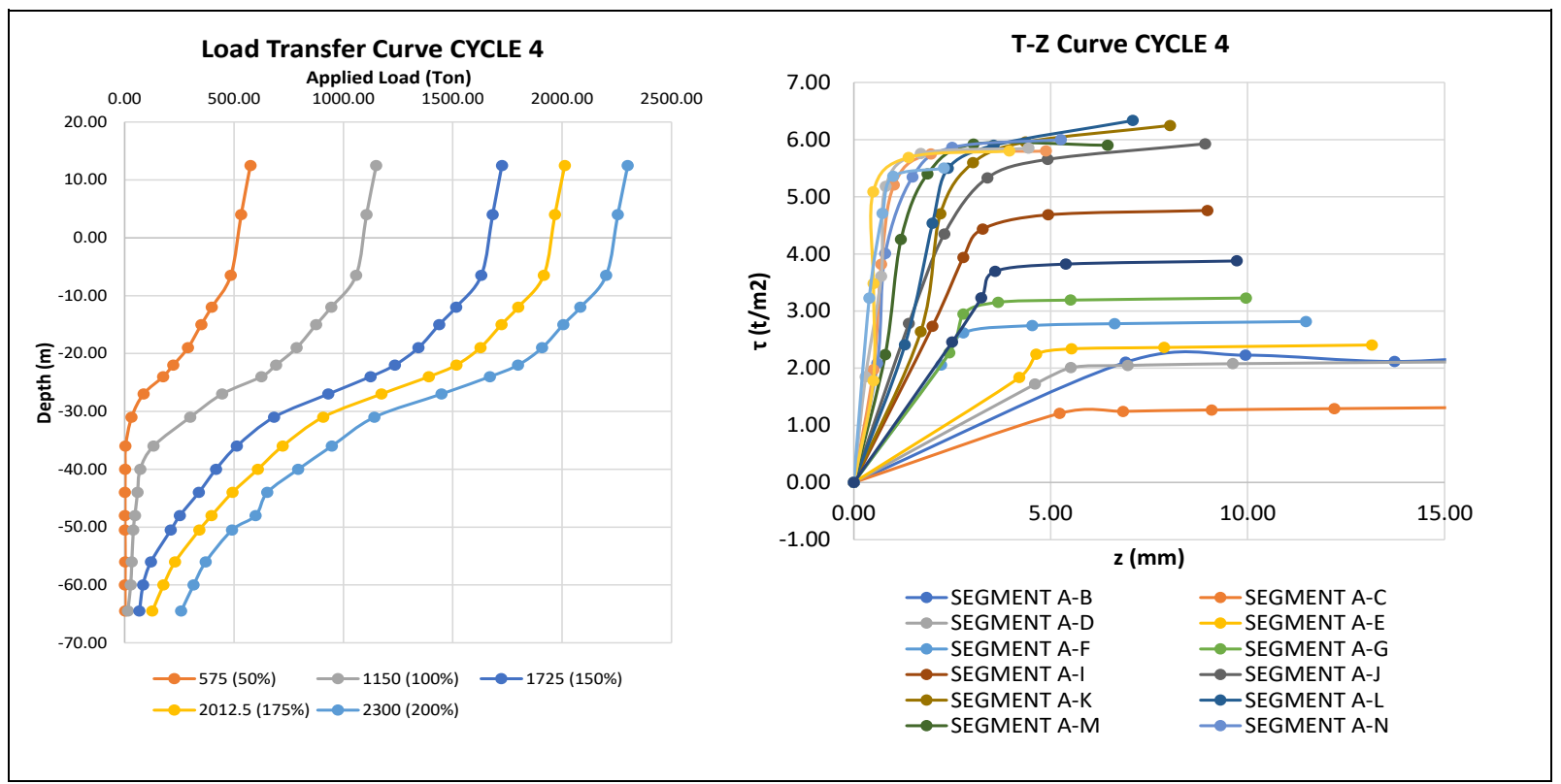

Source : Bored Pile Interface and Expansive Soil on Pile with Bidirectional Test. (2020).

Figure 10. Load Transfer Curve And T-Z Curve of Kentledge System.

Based on the t-z curve in Figure 10, the maximum mobilized skin friction described as $\tau$ is around $6 \mathrm{t} / \mathrm{m} 2$ at pile movement around $4 \mathrm{~mm}$ as this depth consists of stiff clay. The tz curve also shows how the soil behavior acts on certain types of soil. As the soil classification is mostly dominated by clayey soil, the soil behaviour shows strain softening where the soil has reached its peak stress and releases stress afterward. 


\section{Bidirectional Test}

On a bidirectional test, the same concept as the kentledge system, the t-z curve, can be developed to determine the load distribution along with the pile. However, the bidirectional test will show a different type of load distribution. As there are two loading directions (upward and downward), the distribution will be upward and downward as well. The load distribution is then flipped over to produce the equivalent head-down load distribution [20]. This line is known as a total load.

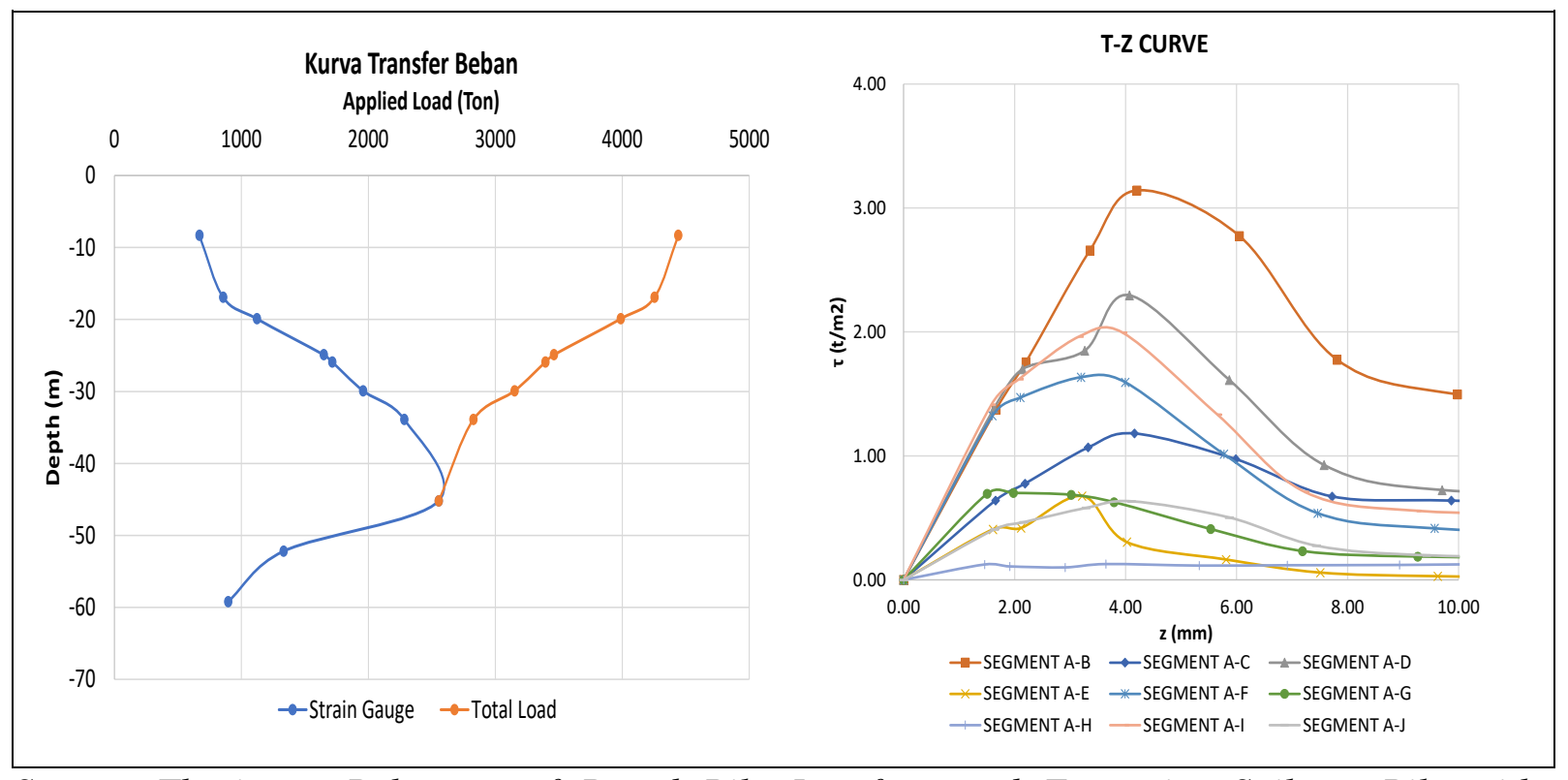

Source: Thesis on Behavour of Bored Pile Interface and Expansive Soil on Pile with Bidirectional Test. (2020)

Figure 11. Load Distribution of T-Z Curve And Bidirectional Test.

The bidirectional test's load distribution curve shows at the depth where strain gauge above o-cell is installed $(-45.2 \mathrm{~m})$. There is a different direction show. The t-z curve shows that the maximum mobilized skin friction is around $3 \mathrm{t} / \mathrm{m}^{2}$ at pile movement around $4 \mathrm{~mm}$.

\section{Conclusion and Suggestion}

\subsection{Conclusion.}

Based on the interpretation result from both methods of pile test, it shows the significant differences between the two. Bidirectional is assured of having more efficiency in time management to perform the work than the kentledge system. From the site's test, mobilized skin friction that occurs along the pile shows a smaller result in the bidirectional test than the kentledge system. 3 
This research would have concluded that there is about a $20-50 \%$ difference in the load distribution of pile under axial load developed by t-z curve from the test result based on bidirectional test and kentledge system. The t-z curve may represent the developed calculation that will describe how different pile behavior under axial load during pile test either using kentledge system of the bidirectional test.

The maximum skin friction mobilized along with the pile under load test of Kentledge is bigger than the bidirectional test. This may occur as the bidirectional test establishes tension force during upward loading. The pile movement at maximum stress mobilized on the pile under axial load is around $2-6 \mathrm{~mm}$ on medium stiff clay. Also, the t-z curve shows the soil behaviour affected by the pile load test tends to be strain-softening soil. Most clayey soil exhibits strain-softening behavior, which can affect the stability of an embankment of a foundation's bearing capacity. Therefore, in the design, there is much consideration in this. There will also be different approaches to the axial load test on sand layer as the soil behavior shows a different curve.

\subsection{Suggestion.}

It is recommended to use better technology instrumentation such as fiber optic to get a more accurate and smooth result of load distribution curve and t-z curve. It is possible to have more strain gauges at close depths to better accuracy. It will give a better approach if to do numerical analysis using the finite element method. 


\section{References}

[1] M. Amirmojahedi, M. Saberizade, and M. Sadeghi, "Fiber optical sensors in Geotechnical Engineering," 5th Int. Conf. Geotechincal Eng. Soil Mech., no. November, pp. 1-11, 2016.

[2] H. S. Salem and B. H. Fellenius, "Bidirectional pile testing : what to expect," no. mm, pp. $1-8,1986$.

[3] B. H. Fellenius and T. S. Ann "Combination of Bidirectional Cell Test and Coventional Head-Down Load Test," ASCE Geotechnical. pp. 240-259, 2010.

[4] E. I. Olalekan et al., "study examines role of indigenous knowledge system in land management," Ecol. Econ., vol. 1, no. 1, pp. 1-7, 2012, doi: 10.1017/CBO9781107415324.004.

[5] A. Kawanda, A. Lim, A. Kwanda, and P. P. Rahardjo, "The Study of t-z and q-z curves on Bored Pile Based on The Results of Instrumented Pile Load Test in Medium and Stiff Clays," no. May, 2013.

[6] W. Conshohocken and U. States, “ASTM-D1143, " PILES UNDER STATIC AXIAL COMPRESSIVE LOAD , STANDARD TEST METHOD FOR ", was adopted on 02MAR-81 for use by the Department of Defense ( DoD ). Proposed changes by DoD activities must be submitted to the DoD Adopting Activity: Commander, A," Policy.

[7] J. Hayes and T. Simmonds, "Interpreting strain measurements from load tests in bored piles," Proc., 9th Int. Conf. Piling Deep Found., pp. 663-669, 2002.

[8] M. England, "Bi-directional Static Load Testing - State of the Art," Deep Found. Bored Auger Piles, 2-4 June 2003, Ghent, Belgium, pp. 309-313, 2003.

[9] J. Rybak, “Osterberg test as an alternative pile testing method OSTERBERG TEST AS AN ALTERNATIVE,” no. June 2015, 2018.

[10] A. I. Candra, A. Yusuf, and A. R. F, "Studi Analisis Daya Dukung Pondasi Tiang Pada Pembangunan Gedung Lp3M Universitas Kadiri,” J. CIVILA, vol. 3, no. 2, p. 166, 2018, doi: 10.30736/cvl.v3i2.259.

[11] A. I. Candra and E. Siswanto, "REKAYASA JOB MIX BETON RINGAN MENGGUNAKAN HYDROTON DAN MASTER EASE 5010,” J. CIVILA, vol. 3, no. 2, p. 162 , Oct. 2018 , doi: 10.30736/cvl.v3i2.258. 
[12] A. I. Candra, "STUDI KASUS STABILITAS STRUKTUR TANAH LEMPUNG PADA JALAN TOTOK KEROT KEDIRI MENGGUNAKAN LIMBAH KERTAS,” UKaRsT, vol. 2, no. 2, p. 11, 2018, doi: 10.30737/ukarst.v2i2.255.

[13] J. C. Chai, J. P. Carter, and S. Hayashi, "Modelling strain-softening behaviour of clayey soils," Lowl. Technol. Int., vol. 9, no. 2, pp. 29-37, 2007.

[14] B. H. Fellenius, "Analysis of results of an instrumented bidirectional-cell test," Geotech. Eng., vol. 46, no. 2, pp. 64-67, 2015.

[15] S. R. Kim and S. G. Chung, "Equivalent head-down load vs. Movement relationships evaluated from bi-directional pile load tests," KSCE J. Civ. Eng., vol. 16, no. 7, pp. 11701177, 2012, doi: 10.1007/s12205-012-1700-8.

[16] C. Bohn, A. Lopes dos Santos, and R. Frank, "Development of axial pile load transfer curves based on instrumented load tests," J. Geotech. Geoenvironmental Eng., vol. 143, no. 1, pp. 2-6, 2017, doi: 10.1061/(ASCE)GT.1943-5606.0001579.

[17] B. H. Fellenius and M. M. Rahman, "Hardening Plastic Softening LOAD (\%) MOVEMENT ( mm ) Load-movement Response by t-z and q-z Functions," vol. 50, no. September 2019, pp. 11-19.

[18] B. Ukritchon, J. C. Faustino, and S. Keawsawasvong, "Numerical investigations of pile load distribution in pile group foundation subjected to vertical load and large moment," Geomech. Eng., vol. 10, no. 5, pp. 577-598, 2016, doi: 10.12989/gae.2016.10.5.577.

[19] B. Ukritchon, J. Faustino, and S. Keawsawasvong, "A numerical study of load distribution of pile group foundation by 2D model," Walailak J. Sci. Technol., vol. 13, no. 8, pp. 669-688, 2016.

[20] M. H. Nguyen, J. E. Garlanger, M. H. Hussein, and G. S. Publication, "Bidirectional-cell tests on two $70 \mathrm{~m}$ long bored piles in Vietnam," pp. 482-496, 2014. 